$$
\begin{array}{r}
\text { CONF-960421--30 } \\
\text { ANL/CNT/CP-88395 RECFIVED } \\
\text { MAR } 27 \text { 1996 } \\
\text { OSTI }
\end{array}
$$

\title{
LONG-TERM CORROSION BEHAVIOR OF ENVIRONMENTAL ASSESSMENT GLASS
}

\author{
W. L. Ebert and J. K. Bates \\ ARGONNE NATIONAL LABORATORY \\ Chemical Technology Division \\ 9700 South Cass Avenue \\ Argonne, II 60439-4837

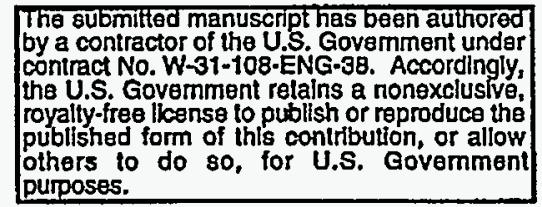

Submitted to

1996 International High-Level Radioactive

Waste Management Conference

Las Vegas, Nevada

April 29-May 3, 1996

Work supported by the U.S. Department of Energy, Office of Environmental Management, under Contract W-31-109-ENG-38. 


\title{
LONG-TERM CORROSION BEHAVIOR OF ENVIRONMENTAL ASSESSMENT GLASS
}

\author{
W. L. Ebert and J. K. Bates \\ Chemical Technology Division \\ Argonne National Laboratory \\ 9700 South Cass Avenue \\ Argonne, IL 60439-4837
}

\begin{abstract}
We have conducted static dissolution tests to characterize the corrosion behavior of the Environmental Assessment glass under conditions relevant to long disposal times. The glass dissolution rate decreased initially, but increased coincidentally with the formation of alteration phases including analcime, gmelinite, and a sodium aluminum silicate hydrate. However, the dissolution rate after those phases formed was less than the rate measured in a 7-day test.
\end{abstract}

\section{INTRODUCTION}

We have conducted static dissolution tests for durations up to about 18 months at high glass surface area/solution volume (S/V) ratios to characterize the behavior of Environmental Assessment (EA) glass ${ }^{1}$ and to determine if the relative durabilities of a waste glass and EA glass measured in a short-term test provide insight into their relative long-term durabilities. Test conditions were the same as those under which alteration phases formed and increased the glass corrosion rate of other Defense Waste Processing Facility (DWPF) reference glasses. ${ }^{2}$

\section{EXPERIMENTAL}

Static dissolution tests were conducted at $90^{\circ} \mathrm{C}$ following the Product Consistency Test (PCT) Method B procedure ${ }^{3}$ from 56 to 527 days at $S / V$ ratios of about 2000 and $20,000 \mathrm{~m}^{-1}$ in a tuff ground water solution. ${ }^{2}$ Leachates were analyzed for $\mathrm{pH}$, anions, and cations, and corroded glass and alteration phases were analyzed with optical microscopy, scanning electron microscopy (SEM) with energy dispersive X-ray spectroscopy (EDS), and $X$-ray diffraction (XRD).

\section{RESULTS}

The normalized mass losses, NL(i), are plotted against the test duration in Figs. 1 and 2 for tests conducted at 2000 and $20,000 \mathrm{~m}^{-1}$, respectively. Boron has the highest normalized release and is used to calculate the glass corrosion rate. Differences in the calculated values of NL(i) indicate that $\mathrm{Si}, \mathrm{Li}$, and $\mathrm{Na}$ are partially incorporated into alteration phases. The corrosion rate of glasses in tests conducted at $2000 \mathrm{~m}^{-1}$ increase from about $0.01 \mathrm{~g} /\left(\mathrm{m}^{2} \bullet \mathrm{d}\right)$ between 30 and 70 days to at least $0.1 \mathrm{~g} /\left(\mathrm{m}^{2} \bullet \mathrm{d}\right)$ after the precipitation of a zeolite alteration phase (see below).

Alteration phases had formed in all tests conducted at $20,000 \mathrm{~m}^{-1}$. The rate measured over the first 200 days is about $0.1 \mathrm{~g} /\left(\mathrm{m}^{2} \cdot \mathrm{d}\right)$. The corrosion rate decreases at longer reaction times due to the loss of surface area as the glass corrodes. For PCT conducted with $-100+200$ mesh crushed glass, the loss of surface area becomes significant when the value of NL(B) exceeds about $20 \mathrm{~g} / \mathrm{m}^{2}$. The nearly constant values of $N L(B)$ in tests at $20,000 \mathrm{~m}^{-1}$ indicate that glass is almost completely corroded after about 1 year.

An alteration layer identified as nontronite, ideally $\left[\mathrm{NaFe}_{6}\left(\mathrm{AlSi}_{11}\right) \mathrm{O}_{30}(\mathrm{OH})_{6}\right]$, coated the glass in all tests at both $S / V$. Three morphologically distinct alteration phases also formed separate from the glass in all tests at $20,000 \mathrm{~m}^{-1}$. These were identified as analcime 
$\left[\mathrm{NaSi}_{2} \mathrm{AlO}_{6} \cdot \mathrm{H}_{2} \mathrm{O}\right]$ g m e 1 in it e $\left[\mathrm{Na}_{2} \mathrm{Al}_{2} \mathrm{Si}_{4} \mathrm{O}_{12}{ }^{\circ} \mathrm{H}_{2} \mathrm{O}\right]$, and a sodium aluminum silicate hydrate $\left[\mathrm{Na}_{5.7} \mathrm{Al}_{5.7} \mathrm{Si}_{10.2} \mathrm{O}_{32} \cdot 12 \mathrm{H}_{2} \mathrm{O}\right]$. An opaque, sodium aluminum silicate hydrate phase having a square bipyramid morphology precipitated in tests at $2000 \mathrm{~m}^{-1}$ run 313 days and longer. This phase had a composition similar to the sodium aluminum silicate hydrate formed in tests at $20,000 \mathrm{~m}^{-1}$, but was morphologically distinct. Analcime also formed in tests at $2000 \mathrm{~m}^{-1}$ after about 407 days.

\section{DISCUSSION AND CONCLUSIONS}

Corrosion of EA glass results in the formation of clay and various zeolite phases, including analcime, gmelinite, and sodium aluminosilicates. Although the dissolution rates increased after these phases formed, the rates were still lower than that measured in a 7-day PCT (at $\left.2000 \mathrm{~m}^{-1}\right)$, which is about $1.2 \mathrm{~g} /\left(\mathrm{m}^{2} \bullet \mathrm{d}\right)$ in deionized water ${ }^{3}$ and $0.7 \mathrm{~g} /\left(\mathrm{m}^{2} \cdot \mathrm{d}\right)$ in tuff ground water solution, based on the boron release. For comparison, the rates measured for SRL 131, SRL 200, and SRL 202 frit-based glasses in 7-day PCT (at $2000 \mathrm{~m}^{-1}$ ) in the tuff ground water solution were $0.2,0.1$, and $0.03 \mathrm{~g} /\left(\mathrm{m}^{2} \cdot \mathrm{d}\right)$, while the rates measured in tests conducted at $20,000 \mathrm{~m}^{-1}$ were $0.05,0.2$, and $0.04 \mathrm{~g} /\left(\mathrm{m}^{2} \bullet \mathrm{d}\right)$ after alteration phases formed. Therefore, the corrosion rate of EA glass measured with a 7-day PCT in deionized water $\left(1.2 \mathrm{~g} /\left(\mathrm{m}^{2} \cdot \mathrm{d}\right)\right.$ provides an upper bound to the corrosion rates of these DWPF glasses, even after alteration phases form. However, the rate measured with the 7-day PCT with EA glass does not bound the long-term rates of all glasses ${ }^{4}$. The formation of alteration phases may increase the dissolution rates of some glasses under repository-relevant conditions. Whether or not alteration phases will form within the time of regulatory concern will depend on the disposal environment and can only be determined by modeling.

\section{ACKNOWLEDGMENTS}

B. S. Tani performed the XRD analyses. This work was supported by the U.S. Department of Energy, Office of Environmental
Management under Contract W-31-109-ENG38.

\section{REFERENCES}

1. C. M. Jantzen, N. E. Bibler, D. C. Beam, C. L. Crawford, and M. A. Pickett, Characterization of the Defense Waste Processing Facility (DWPF) Environmental Assessment (EA) Glass Standard Reference Material, Westinghouse Savannah River Company Report WSRC-TR-92-346, Rev. 1 (1993).

2. W. L. Ebert, and J. K. Bates, "A Comparison of Glass Reaction at High and Low Surface Area to Volume," $\mathrm{Nucl}$. Technol. , 104(3), 372 (1993).

3. Standard Test Methods for Determining Chemical Durability of Nuclear Waste Glasses: The Product Consistency Test (PCT), Standard C1285-94, American Society for Testing and Materials, Philadelphia, PA (1994).

4. W.L. Ebert and D.M. Strachan, Argonne National Laboratory, unpublished information (1995). 


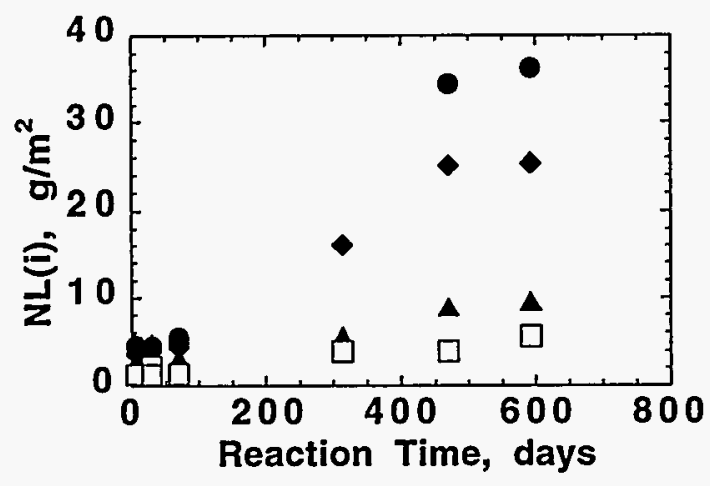

Figure 1. Normalized Mass Loss vs. Reaction Time for Tests Conducted at $2000 \mathrm{~m}^{-1}$. NL(B) $(\bullet), \mathrm{NL}(\mathrm{Li})(\bullet) \mathrm{NL}(\mathrm{Na})(\Delta)$, and NL(Si) ( $\square)$. The line shows the glass dissolution rate in the presence of precipitated alteration phases.

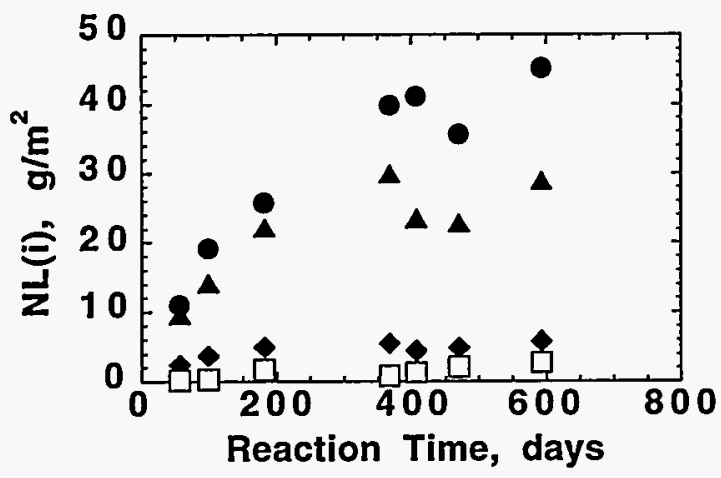

Figure 2. Normalized Mass Loss vs. Reaction Time for Tests Conducted at $20,000 \mathrm{~m}^{-1}$. $\mathrm{NL}(\mathrm{B})(\bullet), \mathrm{NL}(\mathrm{Li})(\diamond) \mathrm{NL}(\mathrm{Na})(\Delta)$, and NL(Si) ( $\square)$. The line shows the glass dissolution rate in the presence of precipitated alteration phases.

\section{DISCLAIMER}

This report was prepared as an account of work sponsored by an agency of the United States Government. Neither the United States Government nor any agency thereof, nor any of their employees, makes any warranty, express or implied, or assumes any legal liability or responsibility for the accuracy, completeness, or usefulness of any information, apparatus, product, or process disclosed, or represents that its use would not infringe privately owned rights. Reference herein to any specific commercial product, process, or service by trade name, trademark, manufacturer, or otherwise does not necessarily constitute or imply its endorsement, recommendation, or favoring by the United States Government or any agency thereof. The views and opinions of authors expressed herein do not necessarily state or reflect those of the United States Government or any agency thereof. 